\title{
Effects of dietary enzyme on broiler chickens fed diets containing wheat bran
}

\author{
S.A. Osei and S. Oduro \\ Department of Animal Science. University of Science and Technology \\ Kumasi, Ghana
}

(Received 17 April 2000; accepted 4 October 2000)

\begin{abstract}
Two hundred and eighty-eight 3-week-old mixed-sex broiler chickens were randomly divided into three dictary treatment groups and fed dicts containing 0,100 or $200 \mathrm{~g} / \mathrm{kg}$ of dictary enzyme. respectively, for four weeks. Feed and water were supplicd ad libitum. The parameters studied included growth rate, feed consumption, feed conversion ratio, carcass evaluation, and the economics of production.

The addition of dietary enzyme significantly reduccd feed consumption $(\mathrm{P}<0.05)$; on the other hand, feed conversion efficiency and growth rate improved significantly with increasing levels of cnzyme incorporation $(\mathrm{P}<0.05)$. The reduction in feed intake compared with birds on the control dict ranged from approximately 10 to $15 \%$. At seven weeks of age, birds on the $100 \mathrm{~g} / \mathrm{kg}$ and $200 \mathrm{~g} / \mathrm{kg}$ enzyme were respectively 1.9 and $5.8 \%$ heavier than their counterparts on the dict with no added enzyme. Birds fed diets containing the highest level of enzyme were $21.1 \%$ more efficient in converting feed to body constituents. Carcass dressing percentage increased significantly with added enzyme $(\mathrm{P}<0.05)$.

Dietary enzyme significantly decreased the total cost of feed per bird and the cost per $\mathrm{kg}$ gain. Enzyme added at $200 \mathrm{~g} / \mathrm{kg}$ diet was the most economical.
\end{abstract}

KEY WORDS: feed enzyme, broilers, wheat bran

\section{INTRODUCTION}

Cereal grains have traditionally been the main sources of energy in commercial broiler diets. In many developing economies with a preponderance of small-scale farms, maize is typically the grain of choice. In addition, various locally available cercal by-products may be used as feed ingredients to varying extents. In Ghana, the main by-products are wheat bran, rice bran and maize bran. These contain anti- 
nutritional factors, principally non-starch polysaccharides (Fincher and Stone, 1986; Cowan, 1990) that limit nutrient availability (Bedford et al., 1991) and impair broiler performance (Donkoh et al., 1994). According to Ferket (1993) the NSPs include cellulose, $\beta$-glucans, pentosans (arabinoxylans) and pectins. The arabinoxylans are of primary concern in wheat and wheat by-products. Chickens lack the endogenous enzymes to hydrolyze NSPs (Easter, 1988), leading to lowered digestibility of fibrous fecd ingredients.

The anti-nutritive effects of NSPs may be overcome by the dictary addition of various exogenous enzyme preparations (Annison, 1991; Friesen et al., 1991). Little work has, however, been done with enzymes in situations where high levels of wheat bran are incorporated in broiler diets as is found on small-scale farms. In Ghana, for example, it is not uncommon to formulate broiler dicts containing a minimum of $150 \mathrm{~g}$ wheat $\mathrm{bran} / \mathrm{kg}$.

This work was therefore undertaken to study the effects of the dietary enzyme, Allzyme PT (Alltech, Nicholasville, Kentucky), on broilers recciving diets containing wheat bran. The enzyme preparation contains (according to the producer) primarily xylanase and pentosanase activities. Other carbohydrases present include galactomannase, $\beta$-glucanase, ccllulase and pectinase.

\section{MATERIAL AND METHODS}

Two hundred and eighty-eight 3-week old locally bred Afabro (from Afariwaa Farms and Livestock Products, Tema, Ghana) broiler chickens of mixed sex were randomly allocated to three dietary treatment groups, each in triplicate, in a completcly randomized design. The chickens were initially individually weighed to obtain the mean for the population. They were then re-weighed and re-allocated such that the mean weights of the treatment groups were similar. Each treatment was equalized for sex. The birds were reared on raised wire floors in wooden coops that allowed a mean floor space of $0.13 \mathrm{~m}^{2}$.

The composition and nutrient content of the basal dict for the trial are shown in Table 1. Birds on the control treatment received the basal diet without added enzyme; birds on the other two treatments received either $100 \mathrm{~g}$ or $200 \mathrm{~g}$ added enzyme per kg of basal diet respectively. Feed and water were provided free choice throughout the experiment.

The parameters measured included daily feed consumption, body weight changes, and feed conversion ratio. Mortalities were recorded as they occurred. At the end of the trials, three birds were randomly selected from each replicate and slaughtered for carcass evaluation. The economics of production was calculated.

All the measured parameters except the economic data were analyzed by the use of the analysis of variance (Wilkinson, 1990). 
TABLE 1

Composition and nutrient analysis of basal diet

\begin{tabular}{lc}
\hline Ingredient & $\mathrm{g} / \mathrm{kg}$ diet \\
\hline Maize & 580.0 \\
Fish meal & 110.0 \\
Soyabean meal & 120.0 \\
Wheat bran & 170.0 \\
Dicalcium phosphate & 10.0 \\
Oyster shell & 5.0 \\
NaCl & 2.5 \\
Vitamin-mineral premix ${ }^{+}$ & 2.5 \\
& \\
Metabolisable energy and nutrient contents, $\mathrm{g} / \mathrm{kg}$ diet & \\
crude protcin & 200.2 \\
crude fibre & 50.9 \\
methionine + cystine & 7.3 \\
lysine & 10.1 \\
arginine & 11.1 \\
tryptophan & 2.2 \\
available P & 5.04 \\
Ca & 10.1 \\
metabolisable encrgy, $\mathrm{MJ} / \mathrm{kg}$ & 12.0 \\
\hline
\end{tabular}

premix supplied the following per $\mathrm{kg}$ of diet: vit. $A 10.000 \mathrm{IU} ; \mathrm{D}, 2,000 \mathrm{IU} ; \mathrm{E} 10 \mathrm{IU} ; \mathrm{K} 3 \mathrm{mg}$; riboflavin $2.5 \mathrm{mg}$; cobalamine $0.05 \mathrm{mg}$; pantothenic acid $5 \mathrm{mg}$; niacin $12.5 \mathrm{mg}$; choline $175 \mathrm{mg}$; folic acid $0.5 \mathrm{mg} ; \mathrm{Mg} 2 \mathrm{~g}$; Fe $0.5 \mathrm{mg}$; Cu $50 \mathrm{mg} ; \mathrm{Zn} 25 \mathrm{mg}$ and Co $625 \mathrm{mg}$

\section{RESULTS AND DISCUSSION}

The effects of dietary enzyme on the performance and carcass traits of broiler chickens are summarized in Table 2 . Fecd consumption significantly declined as the levels of enzyme in the diet increased $(\mathrm{P}<0.05)$. The birds on the highest inclusion rate, $200 \mathrm{~g}$ exogenous enzyme, on the average, consumed approximately $13 \%$ less feed than those on the control. The comparable figure for birds on $100 \mathrm{~g}$ enzyme was $9.6 \%$. Similar observations have been made by other workers (Wiseman and Inborr, 1990; Donkoh et al., 1994). Wiseman and Inborr (1990) have suggested that the decrease in feed intake is due to the ability of fecd enzymes to incrcase the apparent metabolisable encrgy valucs of diets.

Birds on the $200 \mathrm{~g} / \mathrm{kg}$ enzyme diet were significantly heavicr at seven wecks than those on the other two treatments; however, birds on both enzyme diets gained weight significantly $(\mathrm{P}<0.05)$ faster than the control birds.

A significant $(\mathrm{P}<0.05)$ improvement in feed conversion efficiency ranging from $13-21 \%$ was obtained as a result of the addition of enzyme preparation to the basal 
TABLE 2

Effects of enzyme on broiler performance

\begin{tabular}{|c|c|c|c|c|}
\hline \multirow{2}{*}{ Trait } & \multicolumn{3}{|c|}{ Level of enzyme*, g/kg } & \multirow{2}{*}{$\begin{array}{c}\text { Pooled standard } \\
\text { error }\end{array}$} \\
\hline & 0 & 100 & 200 & \\
\hline Mean initial body weight, $g$ & 281.0 & 282.0 & 282.0 & 0.76 \\
\hline Mean final liveweight, $g$ & $1656.0^{\mathrm{a}}$ & $1688.0^{\circ}$ & $1752.0^{\mathrm{h}}$ & 40.27 \\
\hline Mean body weight gain, $g$ & $1375.0^{\mathrm{a}}$ & $1405.0^{b}$ & $1470.0^{\circ}$ & 34.27 \\
\hline Total feed intake, $g$ & $3225.0^{\mathrm{a}}$ & $2901.0^{\mathrm{b}}$ & $2786.0^{\mathrm{c}}$ & 50.12 \\
\hline Average daily feed intake, $g$ & $115.0^{\mathrm{a}}$ & $104.0^{\mathrm{b}}$ & $100.0^{\mathrm{c}}$ & - \\
\hline Fecd conversion ratio, feed: gain & $2.35^{\mathrm{a}}$ & $2.06^{\mathrm{h}}$ & $1.89^{\mathrm{h}}$ & 0.07 \\
\hline Carcass dressing percentage & $74.5^{\circ}$ & $78.1^{\mathrm{b}}$ & $79.4^{c}$ & 1.02 \\
\hline
\end{tabular}

a.b.c $\mathrm{P}<0.05$

- Allzyme PT containing predominantly xylanase and pentosanase activities

diet. Pettersson and Aman (1990) and Fricsen ct al. (1992) earlier reported similar findings. Cowan (1990) reported a 2-3\% increase in efficiency of feed utilisation by birds fed on diets containing enzymes compared with controls.

The improvements in broiler performance resulting from the feeding of dietary enzymes have been attributed to their ability to facilitate access of enzymes to intracellular starch granules, proteins and other nutrients by breaking down otherwise intact bonds between non-starch polysaccharides (Marquardt et al., 1994). In addition, enzymes are known to reduce digesta viscosity induced by the presence of high molecular weight non-starch polysaccharides (Pettersson and Åman, 1989). High digesta viscosity causes reduced feed digestion and slows the rate of nutrient absorption (Bedford, 1992).

The fecding of supplementary enzyme had no influence on the weights of all the internal organs studied. However, there was a significant increase in carcass dressing percentage with increasing dietary levels of the enzyme.

The total cost per $\mathrm{kg}$ feed was slightly higher for the enzyme diets due to the extra cost of the feed enzyme. The control diet cost US\$254 per ton as against $\$ 255$ and $\$ 256$ for the diets containing $100 \mathrm{~g}$ and $200 \mathrm{~g} / \mathrm{kg}$ enzyme, respectively. The respective costs of feed to produce a broiler, however, averaged 81.8,73.9 and 71.4 cents (US) while the corresponding costs per kg body weight gain were 59.5 , 52.6 and 48.6 cents.

\section{CONCLUSIONS}

One of the major problems facing small-scale commercial poultry farmers is that of providing quality nutrition for birds. The use of cercal brans/by-products, while cutting down on costs, is also accompanied by reduced performance (Easter, 
1988). The use of exogenous enzymes cnables the small farmer to incorporate some of these otherwise lowly digested by-products and obtain improved performance and a significant economic advantage.

\section{REFERENCES}

Annison G., 199!. Relationships between levels of soluble non-starch polysaccharides and apparent metabolisable energy of wheat assayed in broiler chickens. J. Agr. Food Chem. 39, 1252-1256

Bedford M.R., 1992. The effect of dictary enzymes on digestion in poultry. Feed Compounder 12 (10), 24-27

Bedford M.R., Classen H.L., Campbell G.I., 1991. Growing interest in feed enzymes to lead to new products. Feedstuffs 63 (4). 96-113

Cowan W.D., 1990. Enzymes in poultry feeds- what are the facts? J. Appl. Poultry Res. 2. 75-81

Donkoh A., Osei S.A., Atuahene Comfort C., Okyere E.R., 1994. Effects of feed enzyme (Roxazyme $\mathrm{G})$ on the performance of broiler chickens. Proc. Ghana Anim. Sci. Assoc. Symp. 22, 83-86

Easter R.A., 1988. Biochemical aids in gastro-intestinal development and function. In: T.P. Lyons (Editor). Biotechnology in the Animal Industry. Proceedings of Alltech's Fourth Annual Symposium. Alltech Technical Publications, Nicholasville. Kentucky

Ferket P.R.. 1993. Practical use of enzymes for broilers and turkeys. J. Appl. Poultry Res. 2, 75-81

Fincher G.B., Stone B.A., 1986. Cell walls and their components in cereal grain technology. In: Y. Pomeranz (Editor). Advances in Cereal Science and Technology. American Association of Chemists, Inc., pp. 207-293

Friesen O.D., Guenter W. Marquardt R.R., Rotter B.A., 1992. The effects of enzyme supplementation on apparent metabolisable energy and nutrient digestibilities of wheat, barley, oats and rye for the young broiler chick. Poultry Sci. 71, 1710-1721

Marquardt R.R., Boros D.D., Guenter W., Crow G., 1994. The nutritive value of barley, ryc, wheat and corn for young chicks as affected by the use of Trichoderma reesei enzyme preparation. Anim. Feed Sci. Tech. 45, 363-378

Pettersson D., Aman P., 1989. Enzyme supplementation of a diet containing rye and wheat. Brit. J. Nutr. 62, 139-149

Wilkinson L., 1990. Systat: The System for Statistics. Systat Incorporated. Evanston. 1llinois

Wiseman J., Inborr J., 1990. The nutritive value of wheat and its effects on broiler performance. In: W. Haresign, D.J.A. Cole (Editors). Recent Advances in Animal Nutrition. Butterworths, London. pp. 79-122 


\section{STRESZCZENIE}

\section{Wpływ dodatku enzymu paszowego na rozwój kurcząt żywionych dietami zawierającymi otręby pszenne}

Dwieście osiemdziesiąt osiem 3 tygodniowych kurcząt obojga płci podzielono losowo na 3 grupy i żywiono przez 4 tygodnie dietami z dodatkiem 0, 100 lub $200 \mathrm{~g} / \mathrm{kg}$ enzymu paszowego. Pasza i woda były dostępne do woli. Oznaczono tempo wzrostu, pobranie i wykorzystanie paszy, wydajność rzeźną oraz koszt produkcji.

Dodatek enzymu paszowego istotnie $(\mathrm{P}<0,05)$ obniżył pobranie paszy od 10 do $15 \%$ w porównaniu z grupą kontrolną, wykorzystanie paszy, tempo przyrostów oraz wydajność rzeźna poprawiły się istotnie $(\mathrm{P}<0,05)$ wraz ze zwiększającym się dodatkiem enzymu. W 7-ym tygodniu życia kurczęta otrzymujące dodatek 100 lub 200 g enzymu do paszy były cięższe odpowiednio o 1,9 i 5,8\% od ptaków kontrolnych. Wykorzystanie paszy przez kurczęta otrzymujące 200 g enzymu było o $21 \%$ lepsze niż przez kontrolne.

Dodatek enzymu do diet istotnie obniżył całkowity koszt paszy w przeliczeniu na ptaka oraz na kg przyrostu, przy czym lepsze wyniki uzyskano przy większej dawce enzymu. 